dr hab. Ewa Gruszewska, prof. UwB

Uniwersytet $w$ Bialymstoku

gruszew@uwb.edu.pl

\title{
OTWARTA NAUKA. REALNOŚĆ CZY FIKCJA
}

\author{
OPEN SCIENCE. REALITY OR FICTION
}

\begin{abstract}
Abstrakt
Przedmiotem badań jest otwartość nauki widziana $\mathrm{z}$ perspektywy ekonomicznej. Za cel artykułu przyjęto odpowiedź na pytanie: jaki jest obecnie stopień otwartości nauki (zwłaszcza nauki w Polsce) oraz jakie są możliwości jej pełnego otwarcia. Przyjęto hipotezę, że poziom otwartości nauki w Polsce jest niski i stanowi ograniczenie na drodze jej rozwoju. Poddano również analizie bariery na drodze do zwiększenia otwartości oraz wskazano skutki niewystarczającego, zdaniem autora, poziomu otwarcia. Analizy podjęte przez autora wykazały, że otwarty dostęp do zasobów nauki jest niezbędnym warunkiem jej rozwoju. Niezbędne jest opracowanie i konsekwentne przeprowadzenie strategii upowszechnienia otwartego dostępu.
\end{abstract}

Słowa kluczowe: dobra publiczne, otwartość, otwarta nauka.

\begin{abstract}
The object of research is the openness of science from an economic perspective. The aim of the article is to answer the question: what is the current degree of openness of science (especially in Poland) and what are the possibilities of its full opening. It is assumed that the level of openness of science in Poland is low and it constitutes a limitation to the development of science. Barriers to increasing openness are also analyzed, and the implications of an insufficient level of openness are indicated. Analysis carried out by the author have shown that open access to scientific resources is a necessary condition for its development. It is essential to develop and consistently implement a strategy for the universalisation of open access.
\end{abstract}

Keywords: public goods, openness, open science. 


\section{Wstęp}

„Otwartość" to kategoria powszechnie znana, jednak zdefiniowanie jej nie jest łatwe. Każdy używa jej do określenia braku przeszkód w czymś, jako przeciwieństwa braku otwartości, czyli zamknięcia, autarkii. Podejmując się dookreślenia terminu „otwartość” należy zacząć od kontekstu, przedmiotu, którego ona dotyczy. W Słowniku języka polskiego pod redakcją W. Doroszewskiego wskazano siedem znaczeń słowa „otwarty”, m.in. '

- niczym nieograniczony przestrzennie;

- skierowany do wszystkich, przeznaczony dla wszystkich lub taki, w którym każdy może wziąć udział;

- taki, który jest gotów na przyjęcie nowych idei lub propozycji; też: o poglądach i postawie takiej osoby;

- jawny i wyraźny.

Wszystkie powyższe znaczenia mogą być odniesione do nauki, jako podstawa wyjaśnienia istoty otwartej nauki i wiedzy oraz pomoc we wskazaniu barier na drodze do w pełni otwartej nauki.

$\mathrm{W}$ artykule podjęto zagadnienie otwartości w nauce w celu interpretacji jego znaczenia. Samo określenie istoty otwartości nie pozwoli jednak na ujawnienie problemów, jakie pojawiają się na drodze ku otwartej nauce. Autorka stara się zgłębić sens otwartości, zwracając uwagę głównie na kwestie ekonomiczne. Stawia przy tym pytanie, czy nauka może być otwarta w pełni i jaki jest aktualny stopień jej otwartości.

\section{Kategoria otwartości. Ujęcie ekonomiczne}

Pojęcie otwartości wykorzystywane jest w ekonomii dla określenia gospodarki, która utrzymuje kontakty z zagranicą; szczególnie istotne są tu eksport oraz import towarów i usług, a także czynników wytwórczych: kapitału, pracy, technologii. Może być odniesione również do przestrzeni mniejszej, np. rynku lub też przedsiębiorstwa. Gospodarka otwarta staje się częścią gospodarki globalnej, choć nie oznacza to, że ma duży w niej udział, czy jest liczącą się gospodarką. Otwarcie jednak daje szansę na zdynamizowanie gospodarki w wielu aspektach. Oczywistym jest, że współcześnie nie istnieją gospodarki całkowicie autarkiczne, choć z całą pewnością

1 Hasło: „otwartość”. W: Słownik języka polskiego. Red. W. Doroszewski. Tryb dostępu: https://sjp.pwn.pl/szukaj/otwartość.html [20 stycznia 2019]. 
istnieją takie, których skala kontaktów z innymi jest niewspółmiernie mała w porównaniu z innymi krajami.

Należy podkreślić, że „otwartość” jest stopniowalna. Istnieją gospodarki w różnym stopniu otwarte lub na różnych poziomach otwartości. Gospodarka nie jest bowiem otwarta lub zamknięta. Żadna nie staje się otwarta z dnia na dzień, na zasadzie włączenia przycisku. Otwieranie się gospodarki to długotrwały proces, w trakcie którego zwiększa się uczestnictwo danego kraju w międzynarodowych obrotach handlowych, turystycznych, kapitałowych. Gospodarka narodowa musi być traktowana jako geograficznie wyodrębniony obszar oddzielony od innych granicami państwowymi. Skala przepływów towarów, usług, kapitału czy siły roboczej staje się miarą siły powiązania danego kraju z innymi, a zarazem stopnia otwartości. Strumienie te w stosunku np. do Produktu Krajowego Brutto (PKB) umożliwiają porównanie otwartości między różnymi gospodarkami. Intensywność wymiany staje się więc podstawą oceny stopnia otwartości. Przykładowym takim wskaźnikiem jest stopa eksportu, czyli wartość eksportu do PKB, czy też wielkość eksportu w przeliczeniu na jednego mieszkańca.

W analizach dotyczących wpływu otwartości na gospodarkę i jej części naukowcy badają często znaczenie handlu zagranicznego dla rozwoju firm i ich dochodów czy inwestycji. W ujęciu makroekonomicznym analizuje się oddziaływanie skali wymiany międzynarodowej (w tym nadwyżki eksportowej) na rozmiary popytu zagregowanego, wskazuje się występowanie efektów mnożnikowych dynamizujących dochody i produkcję. Oczekuje się zwykle, że otwarcie się gospodarki na rynki zagraniczne sprzyja szybszemu wzrostowi gospodarczemu i przyczynia się do wzrostu dobrobytu danego społeczeństwa. Skutkiem otwarcia gospodarki jest wpuszczenie na rynek krajowy podmiotów zagranicznych, czyli poszerzenie i zintensyfikowanie konkurencji. Natomiast konkurencja pobudza kreowanie i implementowanie nowych rozwiązań technicznych, organizacyjnych, wymusza podnoszenie jakości wyrobów i świadczonych usług. Należy wskazać jeszcze jeden oczekiwany skutek otwarcia gospodarki - napływ kapitału zagranicznego. W przypadku krajów, w których dokonała się transformacja systemowa, liberalizacja gospodarki, w tym otwarcie się na rynki zagraniczne, były niezbędnym wymogiem przemian. Modernizacja tych gospodarek w relatywnie krótkim czasie nie byłaby możliwa bez kapitału zagranicznego. Firmy z udziałem kapitału z zagranicy wprowadzały nowe standardy konkurowania, organizacji pracy, nowe strategie zarządzania, co wpływało w oczywisty sposób na podmioty krajowe. 


\section{Nauka i wiedza jako przedmiot wymiany}

Analizując kwestię otwartości w nauce należy zadać sobie pytanie o specyfikę nauki, jako kategorii, którą można „otworzyć”. Jak wskazano powyżej, otwierać można pewną przestrzeń, czego przejawem są strumienie dóbr i usług płynące między wyodrębnionymi obszarami. Produkty nauki stają się przedmiotem wymiany ${ }^{2}$. W przypadku nauki chodzi o strumienie wiedzy, produkty wiedzy, które stają się przedmiotem transferu pomiędzy stronami wymiany: naukowcami, instytucjami badawczymi, uczelniami i podmiotami gospodarczymi. A więc o tym, że nauka jest otwarta świadczyć mogą jej produkty, które są udostępniane szerszej społeczności i mogą być wykorzystywane przez inne podmioty. Jeśli przyjmiemy ten punkt widzenia, to nauka jest otwarta, gdyż jej efekty są publikowane w postaci prac naukowych, czy też wdrażane w postaci innowacji technologicznych, marketingowych, organizacyjnych lub społecznych. Dostęp do takiej wiedzy jest ograniczony jedynie ceną ${ }^{3}$. Jest to podstawowy mechanizm doskonale znany ekonomistom. Rzadkość zasobów (tu: wiedzy) przesądza o konieczności wyznaczenia czy ukształtowania się adekwatnej ceny, która umożliwia zrównanie popytu z podażą danego dobra. Jest to oczywiste w przypadku tzw. dóbr prywatnych. W warunkach wyższej ceny coraz mniej jest osób skłonnych do nabycia danego produktu. Potencjalni odbiorcy mogą poszukiwać sposobów na zdobycie dobra inną drogą niż legalna, ograniczając wówczas koszt zakupu wiedzy, ale też zmniejszając możliwość osiągnięcia dochodu przez wytwórcę tej wiedzy.

Badając istotę wiedzy jako produktu wysiłków i pracy człowieka ${ }^{4}$, i jednocześnie przedmiotu obrotu należy wskazać kilka jej cech. Warunkować one będą wykorzystanie wiedzy i ocenę możliwości otwarcia nauki jako areny

2 Znaczenie wymiany produktów wiedzy jest coraz szerzej podkreślane w pracach naukowych. Zob: A. E. Kuźnar: Międzynarodowy handel produktami wiedzy. Warszawa 2017.

3 Nie można też wykluczyć istnienia badań, których wyniki są z różnych przyczyn utajnione. Wówczas dostęp do takiej wiedzy byłby utrudniony bądź uniemożliwiony administracyjnie.

4 „Tworzenie wiedzy polega na ustanowieniu chwilowych połączeń między różnymi wspólnotami wiedzy, zaangażowaniu rozmaitych technologii, które umożliwiają przepływ informacji-segmentów. Poszczególne moduły są magazynowane w jednym miejscu, przetwarzane i montowane w spójną całość. Wiedza ta powstaje zatem nie tyle „w głowie” pojedynczej osoby, ile raczej w sieciach wiedzy, które tworzą wspólnoty wiedzy, technologie informacyjne [...] i krążące w nich dane”. K. J. Dudek: Sieci wiedzy. Teoria zarządzania między naukq a praktyką. Kraków 2018, s. 166. 
kreowania wiedzy. Będąc wynikiem pracy twórczej wiedza charakteryzuje się następującymi właściwościami ${ }^{5}$ :

- niewyczerpalnością (intensywność i zasięg wykorzystania wiedzy jest nieograniczony);

- symultanicznością (możliwość wykorzystania tej samej wiedzy przez wiele osób w tym samym czasie);

- transferowalnością (możliwość wielokrotnego wykorzystania w różnych miejscach i czasie);

- spontanicznością (żywiołowość w rozprzestrzenianiu utrudnia kontrolę wykorzystania wiedzy);

- nieliniowością (brak stałej zależności między nakładami i wynikami procesu kreowania i zastosowania wiedzy);

- nietrwałością (ciągłą zmianą, „nowa” wiedza zastępuje „starą” wiedzę).

Charakterystyki te wspólnie $\mathrm{z}$ uniwersalnością oraz niematerialnością ${ }^{6}$ sprawiają, że trudno jest traktować wiedzę jako czyste dobro prywatne, ponieważ ma ona również cechy dobra publicznego, np. możliwość korzystania $\mathrm{z}$ danego zasobu wiedzy przez różne osoby w tym samym czasie. Te właściwości zostały wzmocnione dzięki nośnikom elektronicznym i Internetowi.

Dobra prywatne posiadają dwie zasadnicze cechy, odróżniające je od dóbr publicznych. Po pierwsze, są przedmiotem rywalizacji w konsumpcji. Drugą cechą jest możliwość wykluczenia innych osób z wykorzystywania dobra przez właściciela. Rywalizacja w konsumpcji oznacza to, że użytkowanie danego dobra przez jedną osobę uniemożliwia zastosowanie tego dobra do zaspokojenia potrzeb przez inną ${ }^{7}$. Albo konsumuje to dobro jedna osoba, albo druga. Zawsze wtedy, kiedy pojawiają się konflikty na tle problemu ograniczonego dostępu do dóbr, bo zainteresowanych osiąganiem korzyści z danego dobra/zasobu jest wielu uczestników rynku, niezbędne jest znalezienie adekwatnego do sytuacji rozwiązania. Pojawić się powinna powszechna reguła/instytucja, która ograniczy skalę konfliktów oraz uporządkuje sposób korzystania $z$ dóbr ${ }^{8}$. To prawa własności chronią i podtrzymują wolną wymianę . Niezbędnym wymogiem rozwoju

5 B. Poskrobko: Nauka o kreowaniu wiedzy. Podręcznik kreatywnego naukowca i menedżera. Warszawa 2017, s. 73.

6 Tamże, s. 74.

7 J. E. Stiglitz: Ekonomia sektora publicznego. Warszawa 2013, s. 150-151.

8 E. Gruszewska: Instytucje a proces tworzenia kapitału w Polsce. Białystok 2013, s. 315.

9 J. Boehlke: Własność w świetle ekonomicznej analizy prawa. „Ekonomia i prawo” 2007, nr 3, s. 79. 
jest ustanowienie praw własności ${ }^{10}$ oraz ich skuteczne egzekwowanie. Tylko wówczas można zapewnić dostęp do rzadkich dóbr wszystkim, którzy zgłaszają popyt przy danej cenie. Możliwa staje się ich dystrybucja pomiędzy osoby chętne do nabycia.

Każde dobro prywatne jest czyjąś własnością. Jedynie posiadacz dobra ma prawo do czerpania korzyści z zastosowania danej rzeczy, chyba, że sam przekaże je komuś innemu. Wyłączność posiadania i używania oznacza z kolei, że jednostka kontroluje wykorzystanie danego dobra. W przypadku nauki mamy do czynienia $\mathrm{z}$ dobrami, które mogą być traktowane jako dobra prywatne (książki naukowe), ale ponieważ w dużej części pochodzą one $\mathrm{z}$ sektora publicznego i finansowane są z tego źródła, pojawia się presja na ich pełne upowszechnienie ${ }^{11}$. Dobra publiczne cech wyłączności, ani rywalizacyjności nie posiadają, a jednocześnie koszt dostarczenia takiego dobra/usługi kolejnemu użytkownikowi jest równy zeru ${ }^{12}$. Definicja jednak dobra publicznego nie jest precyzyjna i budzi pewne wątpliwości ${ }^{13}$.

Jerzy Kleer zalicza takiego rodzaju usługi jak edukacja, czy też świadczone przez sektor badawczo-rozwojowy do kategorii uniwersalnych dóbr mieszanych, ponieważ muszą być nadzorowane przez instytucje państwowe oraz finansowane przez nie przynajmniej częściowo. Przesądza o tym interes ogólnospołeczny ${ }^{14}$. Model zasilania finansowego badań naukowych przyjęty w Polsce opiera się głównie na źródłach budżetowych, czyli de facto za kreowanie wiedzy płacą wszyscy obywatele w postaci danin publicznych. Trudno uzasadniać zatem sytuację, kiedy kosztochłonne badania umożliwiające osiągnięcie wyników przez naukowca lub grupy badawcze są publikowane w wysoko punktowanych czasopismach naukowych, a jednocześnie czytelnicy - inni naukowcy, aby się z nimi zapoznać muszą zapłacić

10 Już w średniowieczu Tomasz z Akwinu argumentował, że własność prywatna wzmaga pracowitość i przyczynia się do większego porządku w życiu społecznym. Zob. G. Spychalski: Zarys historii myśli ekonomicznej. Łódź 2001, s. 57.

11 Badacze zwracają też uwagę na to, że dobra czysto prywatne mogą przyczyniać się do zaspokojenia potrzeb indywidualnych użytkowników dóbr, ale też generować pozytywne efekty zewnętrzne - mogą sprzyjać korzyściom innych osób; S. Kwiatkowski: Teoria dóbr publicznych i rynkowe mechanizmy ich produkcji. W: Pod prąd głównego nurtu ekonomii. Red. M. Machaj. Warszawa 2017, s. 111.

12 P. A. Samuelson, W. D. Nordhaus: Ekonomia. T. 1. Warszawa 2004, s. 74.

13 J. M. Fijor: Czy dobra publiczne sq naprawdę publiczne? „Studia Ekonomiczne” Nr 1(68) (2011), s. 87-100.

14 A. Kargol-Wasiluk: Teoria dóbr publicznych a paradygmat ekonomii sektora publicznego. „Zarządzanie Publiczne” 2008, nr 3(5), s. 93. 
za korzystanie $z$ tej wiedzy ${ }^{15}$. Dlaczego zatem mają wydatkować pieniądze po raz kolejny, kiedy chcą mieć dostęp do produktów nauki? Należy to traktować jako nieefektywną alokację zasobów.

Można zatem zadać sobie pytanie: czy nauka, a więc i powstająca w wyniku wiedza, nie powinny być dobrami publicznymi? „Rozróżnienie między wiedzą, która powinna pozostawać dobrem publicznym, upowszechnianym $\mathrm{w}$ publikacjach bądź udostępnianym $\mathrm{w}$ ramach partnerskiej współpracy, a wiedzą będącą towarem rynkowym staje się coraz trudniejsze, ale w świecie opartym na współzawodnictwie okazuje się być absolutnie niezbędne"16. Nie ulega też wątpliwości, że coraz trudniej jest kontrolować wykorzystywanie danej wiedzy przez różnych użytkowników (kopiowanie, rozpowszechnianie kopii elektronicznych, nielegalne portale łamiące hasła dostępu do baz wydawnictw), którzy chcą mieć szybki i tani dostęp do najnowszej wiedzy ${ }^{17}$.

\section{Otwartość w nauce}

Brak dostępu lub utrudniony dostęp do wiedzy stanowi problem dla badaczy, którzy chcieliby zapoznać się z wynikami badań innego naukowca. Cena, którą musieliby zapłacić, ogranicza ich możliwość i skłonność do nabycia tego źródła. W warunkach skromnych środków finansowych (nawet przy braku spełnienia tego warunku) i relatywnie wysokiej ceny, mogą zrezygnować z zakupu, a znaleźć prace naukowe o podobnej tematyce, ale bezpłatne. Jeśliby tylko znalazła się okazja, aby jednak zdobyć pożądane dzieło i nie płacić, to pewnie by tak się stało. Byłby to klasyczny przypadek „gapowicza”18. Dobra wspólne są traktowane jakby były niczyje i wydaje się, że są słabo (bo nie bezpośrednio) chronione. Łatwa dostępność dóbr i słabe zabezpieczenia rodzą pokusę, by nie płacić za nie, a wykorzystać dla swoich celów, a jednocześnie nikt na tym specjalnie nie straci. Oczywiście, że stracą wydawcy oraz naukowcy, gdyż utracą potencjalne przyszłe dochody, ale takie przestępstwa są trudno wykrywalne. Otwarcie

$15 \mathrm{Z}$ drugiej strony należy też spojrzeć na interes wydawcy, który czerpie przychody z subskrypcji czy innych form sprzedaży.

16 M. Kleiber: Mądra Polska. Warszawa 2015, s. 557.

$17 \mathrm{Na}$ straży takiego wykorzystywania stoi prawo autorskie i prawo własności intelektualnej.

18 „Gapowicz” (free-rider) opiera swoją decyzję na założeniu, że dane dobro zostało sfinansowane przez inne osoby, a dołączenie jeszcze jednego użytkownika nie przyniesie nikomu uszczerbku, a zwiększy jedynie jego korzyść. 
nauki zwiększa jej transparentność, co ułatwić może dochodzenie praw naukowca, w przypadkach nierzetelności. Umożliwia również utrzymanie i podnoszenie standardów jakości badań i publikacji.

Kategoria otwartej nauki może być $\mathrm{w}$ różny sposób interpretowana. Najpowszechniej stosuje się ujęcie zaproponowane w Budapest Open Access Initiative z 2002 r., w którym przeczytać można, że: „[...] przez »otwarty dostęp « [do recenzowanej literatury naukowej] rozumiemy jej swobodną dostępność w publicznym Internecie, zezwalającą każdemu użytkownikowi na czytanie, ściąganie, kopiowanie, rozpowszechnianie, drukowanie, wyszukiwanie i linkowanie do pełnych treści artykułów, sczytywanie ich w celu indeksowania, przekazywanie danych do oprogramowania lub wykorzystywanie ich w jakikolwiek legalny sposób bez finansowych, prawnych czy technicznych barier, innych niż te, nieodłącznie związane z samym dostępem do Internetu. Jedyna możliwość ograniczania kopiowania i rozpowszechniania oraz ochrony wynikającej z prawa autorskiego - w tym aspekcie - może wynikać z niezbędnej autorskiej kontroli integralności jego pracy i zachowania prawa do bycia poprawnie oznaczonym i cytowanym"19.

Dzięki bardziej powszechnemu dostępowi do prac ich autor-naukowiec można zyskać: większą rozpoznawalność, łatwiejsze nawiązywanie kontaktów z innymi naukowcami i merytoryczną dyskusję z nimi, choć może być też narażonym na krytykę. Należy wskazać też efekt przewagi pierwszego gracza. Naukowiec, który pierwszy się zajmie jakimś zagadnieniem, a dopiero potem zajmą się tym następni, osiąga większe korzyści (czyli „spija śmietankę”, jak mówią marketingowcy). Jednak w przypadku publikowania w otwartym dostępie, „pozytywny efekt otwartości w zakresie cytowań maleje w miarę, jak liczba otwartych zasobów rośnie”20. Wzrost zainteresowania otwartym dostępem zwiększa szum informacyjny i coraz trudniej wyłowić wartościowe publikacje oraz przebić się wśród innych.

Może by więc otworzyć naukę w pełni? Zaoferować dostęp bezpłatny coraz większej liczby wydawnictw? Proces ten został w Polsce zainicjowany kilka lat temu (przykład: https://otwartanauka.pl/baza-wiedzy). W ocenie działalności naukowej zaczęto brać pod uwagę cytowania, a te znacznie łatwiej „zdobyć", gdy artykuły i monografie mają wersje elektroniczne i są łatwo dostępne, np. złożone w repozytorium uczelnianym. Proces

19 Budapest Open Access Initiative. Tryb dostępu: https://www.budapestopenaccessinitiative.org/boai-10-translations/polish [25 stycznia 2019].

20 P. Szczęsny: Otwarta nauka czyli dobre praktyki uczonych. Toruń 2013, s. 27. 
postępował i nadal postępuje w dwóch kierunkach: oddolnie (presja osiągnięć) i odgórnie (tworzenie warunków instytucjonalnych). Zwiększa się liczba wydawnictw oferowanych w sieci w dostępie bezpłatnym, rośnie też liczba w płatnym. Tradycyjne wydawnictwa odchodzą powoli do lamusa, są bowiem mniej dostępne, korzysta z nich ograniczona liczba osób, trudniej z nich korzystać młodym osobom przyzwyczajonym do czytania tekstów na ekranach.

Postępujący rozwój Internetu ułatwia upowszechnianie wyników prac badawczych. Internet stał się doskonałym narzędziem szybkiego przekazywania i odkrywania informacji. Dziś każdy może zapoznać się z pracami naukowców z drugiego krańca świata, choć jeszcze nie do wszystkich dostęp jest jednakowo łatwy. „[... Sposoby dystrybucji i ochrony posiadanej wiedzy są dzisiaj sednem subtelnych analiz korporacji, rządów, organizacji pozarządowych - a sprawa nabierać będzie szybko jeszcze większego znaczenia. Znalezienie odpowiedniej równowagi pomiędzy otwartym dostępem do pewnych rodzajów wiedzy ogólnej - co jest absolutnie niezbędne dla harmonijnego rozwoju cywilizacyjnego w zglobalizowanym społeczeństwie, a skutecznymi metodami ochrony posiadanej wiedzy umożliwiającej tworzenie innowacyjnych produktów i usług - co jest sednem rozwoju gospodarki rynkowej, jest bez wątpienia zasadniczym zadaniem stojącym dzisiaj przed instytucjami powołanymi do wprowadzenia regulacji prawnych w tym zakresie"21.

Rewolucja cyfrowa umożliwiła uwolnienie wiedzy od utrudniającej wymianę cechy: rywalizacyjności w konsumpcji. Dzięki elektronicznej postaci prace naukowe mogą być jednocześnie wykorzystywane przez wielu użytkowników, a koszt dołączenia kolejnego jest równy zeru²2. Większy dostęp to jednak większa pokusa, by wykorzystywać prace innych do osiągnięcia korzyści własnych. Wydaje się, że dużo łatwiej teraz niż w erze przedinternetowej takie oszustwo wykryć. Należy pamiętać, że dobra publiczne nie są dobrami wolnymi, bo ktoś (zwykle państwo) ponosi koszty ich wytworzenia i dostarczenia. Pojawia się zatem kwestia, ile takich dóbr wytwarzać. Nie ma dobrej odpowiedzi na to pytanie. Tylko rynek mógłby ustalić adekwatną podaż w stosunku do zapotrzebowania, ale mechanizm rynkowy jest niedoskonały $\mathrm{w}$ odniesieniu do dóbr publicznych (jest to

21 M. Kleiber: Mądra Polska..., dz. cyt., s. 459.

22 Może się oczywiście pojawić „przeciążenie” serwerów, czy niska przepustowość baz w związku z dużym popytem na wiedzę, ale rozwiązanie tego problemu leży po stronie technicznej. Zob. A. Kargol-Wasiluk: Teoria dóbr publicznych..., dz. cyt., s. 95-96. 
jedna z podstawowych zawodności rynku). Brak jest tu zasadniczego kryterium eliminującego podmioty/przedmioty $\mathrm{z}$ gospodarki, czyli efektywności, sprawności ekonomicznej. Są też takie informacje/prace, które nie mogą być jawne, ze względu na skalę problemów, jakie może to wywołać23.

Ograniczenie dostępu do wyników badań/prac dzięki regulacjom prawnym, może lepiej chronić interes naukowca/instytucji. Bez takiej ochrony wydawcy, a ci w większości wypadków są przecież komercyjni, nie byliby zainteresowani publikowaniem prac naukowych. Interes komercyjny przesądza o utrzymywaniu pism o dużym prestiżu, gdzie za każdą publikację płaci autor oraz czytelnik. Chcąc zapoznać się z pracami tak publikowanymi, trzeba liczyć się dużym wydatkiem, wprowadzane też są embarga czasowe dla dostępu bardziej powszechnego, np. poprzez bazy wykupywane przez instytucje naukowe. Cena, którą musiałby zapłacić potencjalny indywidualny użytkownik, mogłaby być uznana za zbyt wysoką, szczególnie dotyczy to naukowców z krajów słabiej rozwiniętych. Z pewnością ogranicza to dostęp do najnowszej literatury światowej i zmniejsza szanse naukowca na wejście w dyskurs naukowy.

Wydatki na otwarty dostęp i jego infrastrukturę są olbrzymie. Jest to jeden $\mathrm{z}$ najistotniejszych problemów, z jakimi boryka się nauka. Rozwiązania instytucjonalne są nie do końca sprawne, wymagają dużego zaangażowania ze strony naukowca, który umieszczając swoją publikację np. w repozytorium, musi przejść żmudny proces wypełniania dużej liczby komórek. Z drugiej strony, pracując w środowisku uczelnianym, autorka widzi wciąż pewien opór ku szerokiemu upublicznianiu prac naukowych. Wydaje się, że wynika to z jednej strony, z nieznajomości mechanizmów i braku presji/bonusów za publikowanie w otwartym dostępie, $z$ drugiej zaś, z braku umiejętności technicznych i czasu na przejście zawiłości proceduralnych. Powoli się to jednak zmienia, zwłaszcza młodzi naukowcy, widząc zalety publikowania w szerszym zasięgu oraz wykazując brak oporu przed nowinkami technicznymi, będą zmieniali obraz polskiej nauki.

\section{Stopień otwartości nauki}

Zadając sobie pytanie o skalę otwartości nauki w kraju, należy najpierw określić, co jest przedmiotem otwierania w nauce. Na pierwszym miejscu należy wymienić publikacje naukowe, a obok tego dane badawcze. Otwarte

23 P. Szczęsny: Otwarta nauka..., dz. cyt., s. 23-24. 
mogą być też procesy badawcze, recenzje, doktoraty, konferencje ${ }^{24}$. Jak wskazuje praktyka, na świecie dużo szerzej decydują się na otwarty dostęp wydawcy czasopism niż innych publikacji (Wykres 1.). ROAD (Directory of Open Access Scholarly Resources) podaje, że w 2019 r. otwartych było ponad 32 tys. czasopism, 1,8 tys. blogów naukowych, 583 serie monograficzne oraz 393 materiały $^{25}$. Natomiast z danych DOAJ (Directory of Open Access Journal) wynika, że na świecie otwartych jest obecnie 13749 czasopism ze 130 krajów, a w nich ponad 4 mln artykułów ${ }^{26}$.

\section{Wykres 1. Liczba publikacji w otwartym dostępie według danych Directory of Open Access Scholarly Resources (ROAD)}

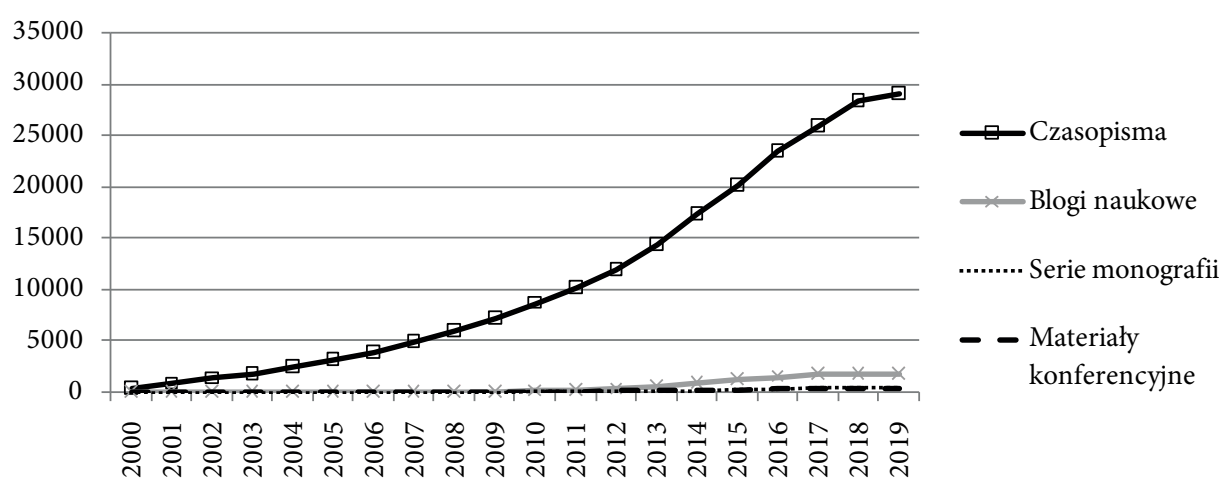

Źródło: ROAD ISSN Portal. Tryb dostępu: https://road.issn.org/ [16 września 2019].

Wydaje się zatem, że łatwiejsze jest opublikowane artykułu w otwartym dostępie niż w monografii naukowej. Rynek czasopism naukowych nie jest miejscem jednorodnym, cechuje go segmentacja związana $\mathrm{z}$ dziedzinami i dyscyplinami naukowymi. W poszczególnych segmentach można wskazać dominujące pisma, wysoko punktowane, w których wypada publikować. Każdy naukowiec, który chce zaistnieć, powinien mieć artykuł/ artykuły w wysoko punktowanych czasopismach. Jest to jeden $\mathrm{z}$ warunków oceny dorobku na potrzeby stopni naukowych i ewaluacji uczelni, w których niezbędne jest wykazanie się osiągnięciami naukowymi. Nowe kryteria oceny, wprowadzane w 2019 r. w Polsce, wskazują lepsze i gorsze

24 Tamże, s. 11-22.

25 ROAD ISSN Portal. Tryb dostępu: https://road.issn.org/ [16 września 2019].

26 DOAJ. Tryb dostępu: https://doaj.org [18 września 2019]. 
wydawnictwa monografii. Będzie to sprzyjało koncentracji prac naukowych w niewielkiej grupie podmiotów o najlepszych ocenach wystawianych przez MNiSW.

Wykres 2. Liczba repozytoriów na świecie według danych ROAD

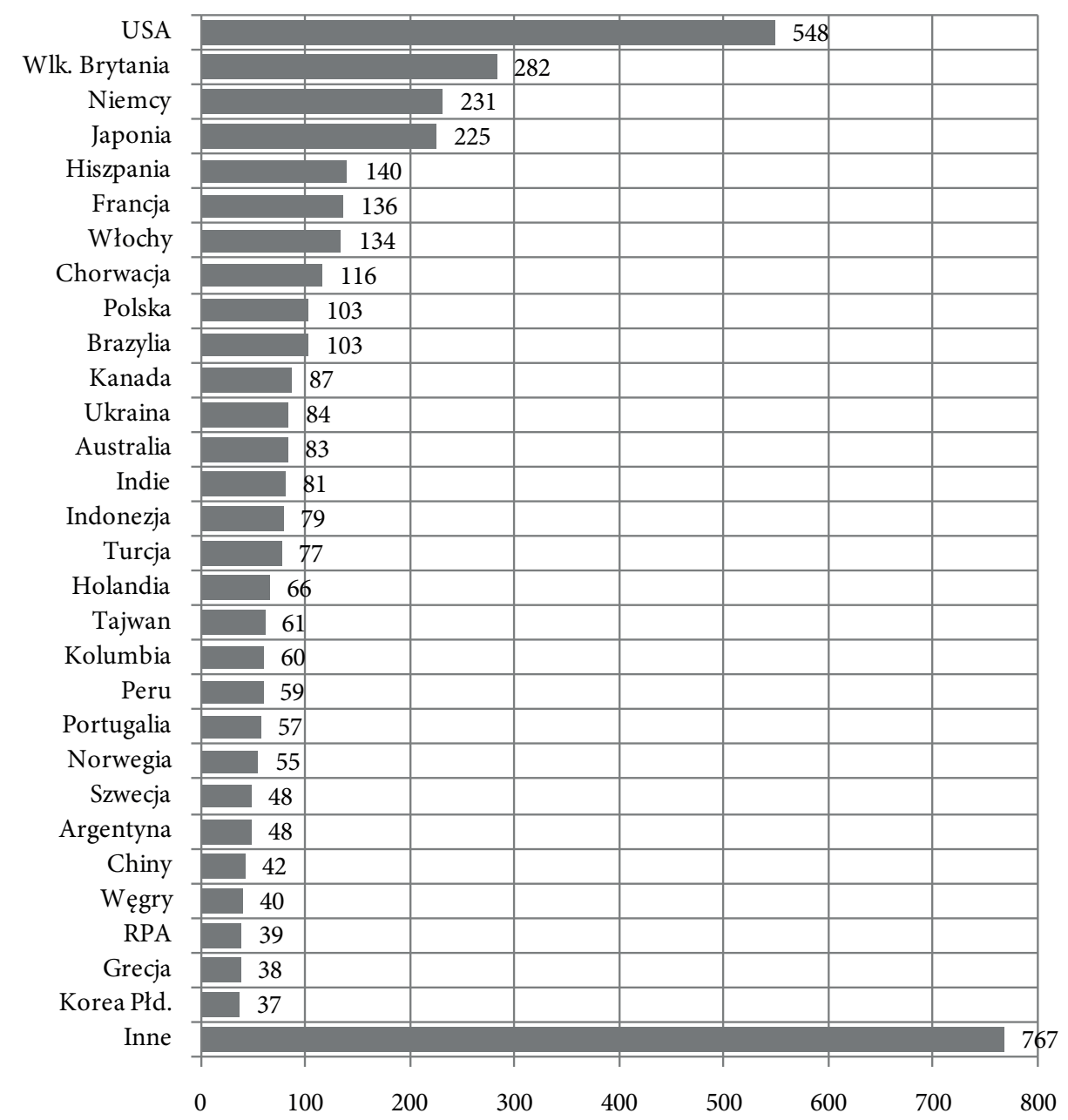

Źródło: OpenDOAR Statistics. Tryb dostępu: http://v2.sherpa.ac.uk/view/repository_ visualisations/1.html [10 lutego 2019].

Publikując w pismach z otwartym dostępem zwiększa się liczbę potencjalnych odbiorców (i cytujących), uruchamia możliwości podjęcia współpracy i konfrontacji swoich wyników badań z innymi naukowcami. Dzięki takim działaniom wzmacniana jest transformacyjna, zasobotwórcza 
i efektywnościowa funkcja nauki (podobnie jak wolność gospodarcza sprzyja handlowi i rozwojowi gospodarczemu). Uwalnianie zasobów przebiega $\mathrm{z}$ dużym udziałem repozytoriów instytucjonalnych. Polska może pochwalić się już sporą liczbą takich archiwów cyfrowych oraz plasuje się na 10 miejscu w świecie, ex aequo z Brazylią (Wykres 2.). Sukcesywnie rośnie też liczba zdeponowanych zasobów. W lutym 2019 roku osiągnęła ona 5,7 mln obiektów cyfrowych ${ }^{27}$.

Presja na publikacje w otwartym dostępie jest coraz większa. Wywołują ją sami użytkownicy, którzy poszukują bezpłatnego lub tańszego dostępu do źródeł. Odpowiedź na to zapotrzebowanie powinna być prosta: więcej wolnych zasobów. Można powiedzieć, że odbywa się znany ekonomistom proces rynkowy: popyt mobilizuje podaż. Odsetek wyszukiwanych źródeł w repozytoriach jest daleko większy (47\%) niż procent artykułów w otwartym dostępie (ok. 28\%). Oczekiwany jest zatem dalszy wzrost skali otwartych czasopism oraz innych zasobów.

Tabela 1. Otwarty dostęp do artykułów z DOI na świecie

\begin{tabular}{|l|c|c|c|}
\hline Typ dostępu & Artykuły z DOI & $\begin{array}{l}\text { Artykuły z DOI } \\
\text { indeksowane } \\
\text { w Web of Science, } \\
\text { lata 2009-2015 }\end{array}$ & $\begin{array}{l}\text { Wyszukiwania cyfro- } \\
\text { wych wersji publikacji } \\
\text { naukowych na bazie } \\
\text { indeksów repozyto- } \\
\text { riów - badanie 1 ty- } \\
\text { dzień w 2017 r. }\end{array}$ \\
\hline Open Access & $27,9 \%$ & $36,1 \%$ & $47,0 \%$ \\
\hline $\begin{array}{l}\text { w tym: } \\
\text { droga złota } \\
\text { droga zielona }\end{array}$ & $3,2 \%$ & $7,4 \%$ & $14,3 \%$ \\
\hline Zamknięte & $4,8 \%$ & $11,5 \%$ & $9,1 \%$ \\
\hline
\end{tabular}

Źródło: The State of OA: A large-scale analysis of the prevalence and impact of Open Access articles. 2017. Tryb dostępu: https://doi.org/10.7287/peerj.preprints.3119v1 [20 grudnia 2018].

W Polsce udział publikacji w czasopismach, które deklarują otwarty dostęp jest zbliżony (Tabela 2.), dodając do tego źródła na licencjach, otrzymujemy ponad 50\%. Świadczy to o dużym zainteresowaniu wydawców elektronicznym dostępem do publikacji. Presja oceny czasopism

27 B. Bednarek-Michalska: W Polsce mamy już prawie $6 \mathrm{mln}$ zasobów cyfrowych online. 2019. Tryb dostępu: https://uwolnijnauke.pl/w-polsce-mamy-juz-prawie-6-mln-zasobow-cyfrowych-online/ [20 lutego 2019]. 
dokonywanej przez MNiSW oraz chęć przyciągnięcia autorów do nadsyłania swoich tekstów, wywołała lawinowy wzrost publikacji w otwartym dostępie. Oby wraz z otwieraniem się czasopism, szła w parze poprawa jakości i wzrost standardów prowadzenia badań, recenzowania oraz publikowania tekstów naukowych. Odpowiadając na pytanie zadane w artykule o możliwość otwarcia nauki, to z pewnością tak jest, że nauka i jej produkty stają się coraz bardziej otwarte, potwierdzają to dane empiryczne i doświadczenia naukowców. Nauka w Polsce otwiera się, jednak jest dużo jeszcze do zrobienia. Do pełnego otwarcia lub akceptowanego poziomu jeszcze daleko. Z pewnością wymaga to szerokich działań ze strony państwa. Niezbędne jest opracowanie i konsekwentne przeprowadzenie strategii upowszechnienia otwartego dostępu. Również po stronie uczelni i instytucji naukowo-badawczych niezbędne są kroki ku zwiększeniu motywacji wśród naukowców, by szerzej eksponowali wyniki swoich badań. Będzie to działanie na korzyść i naukowców, i instytucji, dla których pracują. Korzyści odniesie też cała gospodarka.

Tabela 2. Otwarte artykuły z czasopism w Polsce (2015 i 2016)

\begin{tabular}{|l|l|c|c|}
\hline & Rodzaj licencji & Liczba czasopism & $\begin{array}{l}\text { Odsetek w ogólnej } \\
\text { liczbie }\end{array}$ \\
\hline 1. & CC-BY & 122 & $5,52 \%$ \\
\hline 2. & CC-BY-NC & 39 & $1,76 \%$ \\
\hline 3. & CC-BY-NC-ND & 250 & $11,30 \%$ \\
\hline 4. & CC-BY-NC-SA & 32 & $1,45 \%$ \\
\hline 5. & CC-BY-ND & 66 & $2,98 \%$ \\
\hline 6. & CC-BY-SA & 42 & $1,90 \%$ \\
\hline 7. & OA & 131 & $5,92 \%$ \\
\hline 8. & OA (Bazy) & 475 & $21,47 \%$ \\
\hline
\end{tabular}

Źródło: E. Kulczycki: Stan praktyk publikacyjnych polskich czasopism naukowych w 2017 r. (2018). Tryb dostępu: https://depot.ceon.pl/handle/123456789/15618?show=full [20 grudnia 2018].

\section{Zakończenie}

Otwarty dostęp do zasobów nauki jest niezbędnym warunkiem jej rozwoju. Współczesna gospodarka wymaga nowoczesnej nauki, która będzie źródłem systematycznie odkrywanej wiedzy oraz nowych rozwiązań. Bez działań podejmowanych przez wiele podmiotów może nie przynieść to 
oczekiwanych efektów. Rozwój otwartego dostępu i wzrost jego znaczenia dla nauki byłyby wzmocnione, gdyby państwo podjęło działania w zakresie wsparcia otwartego dostępu. Opracowanie spójnej polityki, strategii rozwoju otwartego dostępu, a następnie konsekwentne ich przeprowadzenie byłoby większą zachętą do zwiększenia zakresu otwartej nauki. Wydaje się, że szczególne znaczenie mają programy wsparcia jednostek naukowych i uczelni w działaniach dotyczących tej kwestii. Wskazane byłoby też wykorzystanie wzorców z innych krajów ${ }^{28}$.

\section{Bibliografia}

1. Access to and Preservation of Scientific Information in Europe. Report on the Implementation of Commission Recommendation C(2012) 4890 final. Brussels 2018.

2. Bednarek-Michalska B.: W Polsce mamy już prawie 6 mln zasobów cyfrowych online. 2019. Tryb dostępu: https://uwolnijnauke.pl/w-polsce-mamy-juz-prawie-6-mln-zasobow-cyfrowych-online/ [20 lutego 2019].

3. Boehlke J.: Własność w świetle ekonomicznej analizy prawa. „Ekonomia i prawo" 2007, nr 3, s. 69-83.

4. Budapest Open Access Initiative. Tryb dostępu: https://www.budapestopenaccessinitiative.org/boai-10-translations/polish [25 stycznia 2019].

5. DOAJ. Tryb dostępu: https://doaj.org [18 września 2019].

6. Dudek K. J.: Sieci wiedzy. Teoria zarządzania między nauka a praktyką. Kraków 2018.

7. Fijor J. M.: Czy dobra publiczne sq naprawdę publiczne? „Studia Ekonomiczne” Nr 1(68) (2011), s. 87-100.

8. Gruszewska E.: Instytucje a proces tworzenia kapitału w Polsce. Białystok 2013.

9. Kargol-Wasiluk A.: Teoria dóbr publicznych a paradygmat ekonomii sektora publicznego. „Zarządzanie Publiczne” 2008, nr 3(5), s. 91-117.

10. Kleiber M.: Mądra Polska. Warszawa 2015.

11. Kulczycki E.: Stan praktyk publikacyjnych polskich czasopism naukowych w 2017 roku. (2018). Tryb dostępu: https://epot.ceon.pl/handle/123456789/15618? show=full [20 grudnia 2018].

12. Kuźnar A. E.: Międzynarodowy handel produktami wiedzy. Warszawa 2017.

13. Kwiatkowski S.: Teoria dóbr publicznych i rynkowe mechanizmy ich produkcji. W: Pod prąd głównego nurtu ekonomii. Red. M. Machaj. Warszawa 2017, s. 95-119.

14. OpenDOAR Statistics. Tryb dostępu: http://v2.sherpa.ac.uk/view/repository_ visualisations/1.html [10 lutego 2019].

28 Wiele państw prowadzi działania i realizuje strategie mające na celu upowszechniania otwartego dostępu do publikacji i do danych badawczych na poziomie krajowym. Zob. Access to and Preservation of Scientific Information in Europe. Report on the Implementation of Commission Recommendation C(2012) 4890 final. Brussels 2018, s. 27. 
15. Poskrobko B.: Nauka o kreowaniu wiedzy. Podręcznik kreatywnego naukowca i menedżera. Warszawa 2017.

16. ROAD ISSN Portal. Tryb dostępu: https://road.issn.org/ [16 września 2019].

17. Samuelson P. A., Nordhaus W. D.: Ekonomia. T. 1. Warszawa 2004.

18. Słownik języka polskiego. Red. W. Doroszewski. Tryb dostępu: https://sjp.pwn. pl/szukaj/otwartość.html [20 stycznia 2019].

19. Spychalski G.: Zarys historii myśli ekonomicznej. Łódź 2001.

20. The State of OA: A large-scale analysis of the prevalence and impact of Open Access articles. 2017. Tryb dostępu: https://doi.org/10.7287/peerj.preprints. 3119v1 [20 grudnia 2018].

21. Stiglitz J. E.: Ekonomia sektora publicznego. Warszawa 2013.

22. Szczęsny P.: Otwarta nauka czyli dobre praktyki uczonych. Toruń 2013. 